Mediterranean Journal of Humanities mjh.akdeniz.edu.tr III/1, 2013, 15-28

\title{
Sanatçının Kimliği Olarak Geçmişi Bağlamında Nan Goldin ve Nobuyoshi Araki Örnekleri
}

\author{
The Examples of Nan Goldin and Nobuyoshi Araki in the Context of an Artist's \\ Past as their Identitiy
}

\begin{abstract}
Şahinde AKKAYA*
Özet: İnsan, kendinin farkına vardığı andan itibaren kim olduğunu anlamaya dair bir çaba içine girmektedir. İnsanın, bu çabası, kendi kendisini inşa etme projesidir. Bu özgül bir deneyimi ve yaratıcı bir arayışı zorunlu hale getirir. Kimlik, tanımlanması oldukça güç ve çok katmanlı bir kavramdır. İnsanı, dış dünyaya karşı tanımlayan, onun tüm özelliklerini ve niteliklerini kapsayan bir kavramdır. Kimlik, kişiliğin inşasının temel taşlarındandır. Kimlikler birer aidiyet göstergesidir; ancak insanı tekil bir birey olarak yeri doldurulamaz ve farklı kılan 'öz' kimliğidir. Bireyin sorgulayarak anlamlandırmaya çalıştığı temel kimliği budur. Kendi ‘öz’ünü bilme ve anlamlandırma çabası içinde olan sanatçı da, kimliğini bir ifade aracı olarak gördüğü sanat yoluyla oluşturur. Bu bağlamda, yaratım süreci içerisinde sanatçının hissettiklerini anlaması kendi kimliğini bulmasının önemli bir parçasını oluşturmaktadır. Sanatçı bu süreci, yaşamsal deneyimlerini aktardığı eserleri aracılığıyla yaşamaktadır. Bu nedenle, sanatçı kimliğinin oluşumunda, kişinin geçmişinin rolü büyük önem taşımaktadır. Bu çalışmada, yaşam deneyimlerini eserlerinin ana temalarına yerleştiren ve bunu geçmişle uzlaşma ve bir çeşit kendini iyileştirme aracı olarak kullanan Nan Goldin ve Noboyoshi Araki örnekleri incelenmiştir.
\end{abstract}

Anahtar sözcükler: Kimlik, sanatçı kimliği, fotoğraf, Nan Goldin, Nobuyoshi Araki

Abstract: From the moment when the person awares of himself/herself goes into an effort of selfunderstanding. This effort is person's project to build himself. This effort makes necessary for a specific experience and a creative pursuit. Identitiy is a very difficult and multi layered concept to define. Identitiy is a concept that defines a person towards outer world and encompasses a person's all capabilities and characteristics. In this context identitiy is the one of basic keystones of the building of personality. Identities are indicative of a sense of belonging but; 'self' identitiy is the most significant one that makes person irreplaceable and different as an individual. This is the basic identity of an individual trying to make sense by questioning. The artist that attempts to understand his/herself builds identitiy through the medium of art forms which seen as a means of expressing. Within this context, to understand the artist's own feelings in the process of creation is a very important part of discovering the artist's own identity. The artist lives this process through works that transpose personal experiences. Therefore, the person's own history has a great importance in the formation of the identity of the artist. In this study, the main themes of the works concerning their life experiences concerning a kind of reconciliation with the past as a means of self-healing were analysed using the examples of Nan Goldin and Nobuyoshi Araki and their works.

Keywords: Identity, artist identity, photography, Nan Goldin, Nobuyoshi Araki

\footnotetext{
*Fotoğraf Sanatçısı, İstanbul, sahinde@gmail.com
} 


\title{
Kimlik ve Sanatçı Kimliğinin İnşası
}

İnsanın, dünyaya geldiği andan itibaren 'kim' olduğunu anlamaya dair çabası, varoluşunun en büyük sorunlarından biri olarak karşısına çıkmaktadır. Sokrates'in 'kendini bil' deyişi, antikçağ filozoflarından bu yana insanın kendisini tanıma ve anlama uğraşının en temel göstergelerindendir.

\begin{abstract}
"Kişi kendi doğası ile sahici bir ilişkiye girdiği andan itibaren, yakından tanımaya çalıştı̆̆ varliğının, esasen tahmin edilenden daha uzakta ve derinlerde, tıpkı dünyanın başlangıcında olduğu gibi sabit bir nokta üzerine kurulu, hiç kımıldamayan ve sonu gelmeyecek meseleler üzerine adeta bir savaşın ortasında yer aldiğını görecektir. Böyle gerilimli bir 'savaş'ın öznesi olmak, daha en baştan varoluşun bin bir türlü zahmetine işaret eder. [...] Dünyaya gelmiş olmanın verebileceği bir hayret ve şaşkınlık içerisinde, insanın kendisini hep aşması gerektiği varoluşun en anlamlı sorusu olarak kişinin kendisiyle savaşını gündeme getirir" (Takış, 2009,7-8).
\end{abstract}

Kişinin kendisiyle olan savaşı, kendi kendisini inşa etme projesidir. Bu özgül bir deneyimi ve yaratıcı bir arayışı zorunlu hale getirmektedir. Kişiyi dış dünyaya karşı tanımlayan, onun tüm özelliklerini ve niteliklerini kapsayan bir kavram olan kimlik ise kişiliğin inşasının temel taşlarındandır. "Kişilik, bireyin kimlikler içinde ve kimliklerle bir örgütlenmesidir. Zira birey, kimlikler aracılığlyla toplumsal çevreye uyum sağlar"(Aşkın, 2007, 213).

Kimlik en genel hatlarıyla, bireyin tüm özelliklerini kapsayan bir kavram olarak; hem bireyin kendisini nasıl gördügünü hem de toplum tarafından nasıl görüldüğünü tanımlamaktadır. Kimlik kavramı, geçmişi çok gerilere dayansa da asıl olarak 20. yüzyılla birlikte modernitenin bir sonucu olarak düşünülmeye ve tartışılmaya başlanmıştır. Kimliğin nasıl oluştuğu sorusu üzerine odaklanan bu tartışmalarda öznelci ve nesnelci olmak üzere iki yaklaşım mevcuttur. Öznel yaklaşıma göre, kimlik tutarlı ve yaşam boyu pek değişim göstermeyen gerçek 'ben'dir; ancak öznelci yaklaşım sadece bireyi, onu dış dünyadan soyutlayarak ele almaktadır. Nesnelci yaklaşım ise insanın sosyal bir varlık olmasından ötürü, kimliğin sadece iç dinamiklerle oluşmadığını; onu çevreleyen dış etmenlerin de kimliğin oluşum sürecini etkilediğini ve bu etkileşimin bir sonucu olarak kimliğin tutarlı bir yapıya büründüğünü savunmaktadır. Nesnelci yaklaşımın en önemli kuramlarından olan sosyal kurama göre kişi ‘ben' olduğunun farkındadır ve kendisini 'öteki' kişilerin tutumlarına göre konumlandırmaktadır. Başka bir deyişle kimlik, öznenin önce kendisini tanıması sonra diğerlerinin tutumlarını öğrenmesiyle geliştirilen süreçler bütünüdür. Böylece, öznenin diğer öznelerle dil ve temsil aracillğıyla kurduğu iletişim sonucunda kimlik oluşmaktadır. Kimlik öznel bir bütünlüğü, tutarlılığı ve sürekliliği içermektedir; bireyi diğer bireylerden ayıran, tutarlı ve yapılanmış göstergeler bütünüdür. Ancak kimlik tek katmanlı değildir; bireyin yaşantısında onu tanımlayan birçok kimlik yer alır: Yalın insan kimliği, genetik kimlik, kültürel kimlik, ulusal kimlik, ekonomik kimlik gibi...

Kimlik bireysel bir olgudur; ancak kişinin kendi özü ve dışarıyla yaşadığı etkileşim yoluyla şekillenmesinden ötürü, toplumsal yapı bireysel kimliği zaman içinde değişime uğratabilmektedir. Modernite ile birlikte toplumsal kurumlar, bireye içinde yaşadığı yapının değerleri yoluyla yeni kimlikler yükleme eğilimindedir. Giydirilmiş kimlikler olarak tanımlanan bu kimliklerin altında ise insanın sahip olduğu 'öz'ünün barındığ 1 yalın insan kimliği yer almaktadır (Aşkın, 2007, 213-220). 
"Tarih, zaman, toplum, çevre, gelenek ve kurallar, paylaşllan kent ve mekanlar bizi gösteren, bizi bütünüyle kuşatan kimlik aynasının daha gelişmiş parçalarıdır. Ben'in kuvvetle içerimlediği 'öteki' algısı, etnik, dinsel farklılıklar, ekonomik-sinıfsal ayrumlar, (efendi ve köle diyalektiği), aile geleneği, cinsiyet $v b$. konumlandirmalar kimliklerin şekillenmesinde belirleyici rollere sahiptirler" (Tak1ş, 2003, 6).

Kişi, bir yandan kendini tanıma ve bilme uğraşıyla öz kimliğini oluşturma ve tek başına bir birey olma çabası içinde yer alırken öte yandan yaşadığı çağdaş dünyanın ve üyesi olduğu toplumsal yapının dinamikleriyle de etkileşim içine girerek özdeşleşmeye çalışmaktadır. Hem öz kimliğini bulmaya hem de özdeşleşmeyle gelen aidiyet karşısında kendisini, öteki insanların içinde farklı bir birey olarak konumlandırmaya çalışan kişi, bu noktada kimlik kavramının paradoksuyla karşılaşmaktadır.

\begin{abstract}
"Kimlik kavramı, hem varoluşunu borçlu olduğu, hem de bu varliğı sürekli sakatlayan iki ana paradoksun kiskacındadır. Bu paradokslardan birincisi kavramin adından ve bu adin nominal-tarihsel arka planindan kaynaklanmaktadır. Batı dillerinde Latince'nin idem (aynı) kökünden türetilen identité-identity kelimesi bir özdeşliği, aynıllı̆ı ifade etmektedir. [...] Demek ki kavram ana işareti ve yönelişi itibariyle tercih küresi içinde yer almayan bir mensubiyeti, bir aidiyeti bir çoklukla aynılaşmayı göstermektedir" (Kılıçbay, 2003, 155).
\end{abstract}

Kişilerin sahip olduğu tüm kimlikler, bir aidiyet göstergesidir ancak kişiyi tekil bir birey olarak yeri doldurulamaz ve farklı kılan kendi iç zenginliğini ve değerini oluşturan kendi 'öz' kimliğidir. Bireyin sorgulayarak anlamlandırmaya çalıştığı temel kimliği budur. Kendi ‘öz'ünü bilme ve anlamlandırma çabası içinde olan sanatçı da kimliğini bir ifade aracı olarak gördüğü sanat yoluyla oluşturmaktadır. Ancak kimlik bir oluşum sürecidir ve bu süreçte kendisinin farkına varan kişi, kimliğine ulaşma çabasıyla 'ben kimim?' sorusuna karşı bir cevap bulma arayışına girmektedir. Kimliğini bulmaya çalışan sanatçının yaratma güdüsü de bu arayıştan kaynaklanmaktadır. Sanatçının kimliğinin oluşumunda, kendi iç dünyasına bakışı kadar, onu çevreleyen ve etkileşim içinde olduğu dış dünyanın yansımaları da etkilidir. Bu nedenle sanatçının kimliğini oluşturan tek bir etkenden söz edilemez; onu etkileyen iç ve dış birçok faktörün bir araya gelmesidir. Sanatçıyı diğer insanlardan ayrı bir konuma yerleştiren de benliğini oluşturan bu izlerin yarattığı çatışmaların farkına varması ve bu çatışmalardan doğan karşıtlıklardan bir bütün oluşturmaya çalışarak benliğindeki karmaşayı düzene oturtma isteğidir. Kişinin, kendini keşfetme ve öz kimliğini bulma sürecinin kendi izini bırakma duygusundan kaynaklandığ söylenebilir.

"Sanatçının süreç içinde ne düşündüğünü ve hissettiğini anlaması kendi kimliğini bulmasının bir bölümünü oluşturacaktır. Eser üretme de bunun bir yolu olarak görülmektedir. Eserlerin her biri benliğin gerçek yaşam öyküsünü aktarmaktadır. Her bir süreç yeni bir arayışın eserlerini verir. Imgelemde yeni oluşumların ne zaman ve nasıl ortaya çıkacağı belirsizdir. Yaratım sürecinin etkili bir biçimde ilerleyebilmesi için kişisel kimlik duygusu gereklidir" (Uysal, 2006, 118).

$\mathrm{Bu}$ bağlamda, kişinin varoluşunu sanatsal üretim yoluyla ortaya koymasının ve sanat eseri yaratma nedeninin bir nevi ölümsüzlük çabası olduğu düşünülmektedir. Rank'ın sanat yapıtının özüne ilişkin değişmeyen durum olarak söz ettiği de ‘ölümsüzlük' düşüncesinin sanat yapıtının 
oluşumunda etken olduğu gerçeğidir.

"Rank'a göre sanatın belirli bir dönemde aldı̆̆ form o dönemde geçerli olan 'ölümsüzlük ideolojisine' göre belirlenir. Buna göre; ölümsüzlük fikri 'ruh' fikrini, bu fikir de 'ruhun ifade edilmesine' yönelen sanatlart doğurmuştur. [...] Bir anlamda sanatın, soyut ruh kavramına, o dönemde hâkim olan güzellik ideolojisi çerçevesinde, kendisini 'somut' olarak ifade etmesini sağlayacak bir araç verdiğini savunmak mümkündür. Başka bir söyleyişle, hem toplum hem de bireysel sanatçının ölümsüzlük özlemi ve bu özlemin ruh kavramı içindeki yansıması, belirli bir somut biçime ve buna bağll olarak bu biçimin nasıl olması gerektiğine ilişkin fikirlere dönüşerek, bir dönemin sanat anlayışına yön verir. Bu bakımdan sanat işlevsel bir olgudur, ölümsüz ruh kavramının dış dünyada nasıl, hangi somut yöntemle ifade edileceğini gösterir, ölümsüzlük fikrine gözle görülür bir form kazandırır" (Cebeci, 2008, 44-45).

Sanatçı, benliğindeki kompleks yapıdan kaynaklanan duygulanımları somut bir sanat eserine dönüştürmek yoluyla ölümsüz ruh kavramını somutlaştırmaktadır. Bu süreçte yaratıcılık ve ruhsal durum ilişkisi birbirinden ayrı düşünülemez. "Yaratıcılı̆̆ın kendi özel kültürümüzde ciddi psikolojik sorunlarla bütünleştiği bir muhakkak -Van Gogh çıldırıya kapıldl, Gaugin içe kapanık (schzoid) görünüyor, Poe alkolikti ve Virginia Woolf ciddi bir çöküntü içindeydi. Yaratıcıllk ve özgünlügün kültürlerine uymayan kişilerde bütünleştiği apaçık” (May, 2008, 61). Ancak May, bu durumun yaratıcılığın zorunlu olarak nevrozdan kaynaklandığı anlamına gelmeyeceğini söyler (May, 2008, 61).

Sanatçı, benliğindeki karmaşayı, benlik nesnesi olan sanat eseri yoluyla düzene oturtmaktadır. Kohut'un benlik psikolojisi kuramında söz ettiği benlik nesnesi(self-object) terimi, kişinin duygusal yatırım yaptığı az ya da çok benliği içine yerleşmiş nesnelerdir ve benliğin devamını, bütünlüğünü korumak ve beslemek görevini üstlenirler. Benlik kapasitesini duygulanım ve gelişim bakımından destekleyen benlik nesneleri görevlerini düzgün bir biçimde yerine getirdiklerinde benliğin kuruluş, devamlılık, sağlamlık, değişim gibi özelliklerini korurlar. Yaratıcı süreçte sanatçı büyük bir istekle, aslında benlik nesnesi olan şeyleri sanat nesnesi olarak bulmakta ve onları sanat eserine dönüştürmektedir. Sanatçının eseriyle yansıttığı, benliğinin derinlerine yerleşmiş olan benlik nesnelerini kesin bir istekle bulup çıkartmasıdır. Sanatçı, nesnelleştirdiği duyguları ve seçtiği sanatsal materyalleri kullanarak estetik elementler yoluyla bir sanat nesnesi yaratmakta ve gerçekte bu sanat nesnesinin altında, açıklamak istediği yaşantısal durumu yatmaktadır. İzleyici baktı̆̆ 1 eserden etkilendiğinde sanatçının anlatmak istediği yaşamsal ilişkilerin farkına varmış demektir. Sanatçının, benlik ile benlik nesnesi arasındaki ilişkiyi aktardığı sanat yapıtı, o anda hissettiklerinin sembolize edilmiş hâli olarak kalıcı bir iz bırakmaktadır. Yaratım sürecinde esere aktarılanlar, sanatçının o anki benliğinin içinden kaynaklanan etkenlerden ötürü ayrı bir özellik taşır; o ana özel yoğunluk, biçim ve kompozisyon seçilmiştir. Bu nedenle yaratılan eserin başka bir zamanda, aynısının, aynı şekilde yapılması mümkün değildir. Yaratılan eser o ana özel, benzersizdir; çünkü yaşanılan deneyim ve o anda hissedilen duyguların dışavurumudur (Güney, 1999, 42-45).

Sigmund Freud tarafindan geliştirilen psikanaliz kuramına göre sanatsal yaratılar, bilinç dışına itilen dürtülerin bir tür dışavurum yoluyla sanat eserine dönüşerek psişik yapının deşarj edilmesi olarak tanımlanabilir. "[...] Sanatçının yaşam öyküsünün hem biyografik verilerden, hem de ürettiği yapıtlardan yola çıklarak yeniden kurgulanmasını ve yine bu kurgudan yararlanılarak eserlerinin tekrar yorumlanmasını hedefleyen psikobiyografi türünün doğmasına yol 
açmıştır" (Cebeci, 2008, 8).

"Freud yaratıcıllğ̆ bilinçdışı uyarılmalar ve çatışmaların yüceltilmesi olarak görmüştür. Yaratıcılığın, ölümlü olduğunu bilen tek canlı olan insanın, ölümsüzlügüun karşısına oturttuğu bir çeşit savunma mekanizması olduğu söylenebilir. Ölümsüz olmanın olanaksızlı̆̆ını bilen sanatçı, yaratıcılığını kullanarak meydana getirdiği sanat yapıtları aracılı̆̆ıyla, kalıcı olma ve ölümün ötesine geçmeye dair bir çaba içindedir. Freud, sanatçının baskı altında tuttuğu dürtülerini, itilerini, düş gücü ve imleme ile doyuma ulaştırmaya çalıştığını öne sürer. Sanatçının yaratma nedenlerinin gerisinde yaşam öyküsü, kişiliği ve davranışları yatar. Örneğin Dostoyevski'nin babasina olan nefreti, onun ölmesini istemesi, ama bundan suçluluk duyması Karamazov Kardeşler adlı romanında yansımasinı bulur" (Ezici, 2005, 125).

Kişinin çocukluk döneminde yaşadıkları, yetişme/yetiştirilme koşulları, geçmişini oluşturan etkenler olarak kuşkusuz her insanın benliğinin oluşumunda büyük role sahiptir. Sanatçıyı diğer insanlardan ayrı bir noktaya taşıyan, benliğindeki çatışmaların farkına vararak onları düzenleme uğraşıdır. Bu nedenle, sanatçının geçmişini etkileyen ya da çeşitli travmalara yol açan sorunları eserleri aracılığıyla yansıtmasının, bu sorunlarla yüzleşerek bir çözüme ulaşma yolu olduğu kabul edilmektedir. Kendini tanıma ve anlamlandırmaya çalışan sanatçı, benliği ve benlik nesnesi arasındaki ilişkiyi estetik elementler yardımıyla sanat yapıtına dönüştürerek kimliğini oluşturmaya çalışmaktadır. "Yaratıcı süreç içinde sanatçının benlik nesnelerini kullanarak benliğinin özüne daha çok yaklaşmış olduğu ve bunun da benliğin gelişmesi ve bütünlenmesine yardımcı olduğu söylenebilir" (Güney, 1999, 45).

Sanatçıyı yaratıcılık için motive eden etmenler ve bu süreçte içsel yaşantısının durumu, psiko-biyografisinin önemi, benliğindeki karmaşayı düzenleme çabasındaki sanatçının kimliğinin oluşmasına kaynaklık eden faktörlerdir. Bu bağlamda, kişisel deneyimlerini fotoğraflarının konusu haline getirerek bu süreci eserleri aracılığıyla yaşayan Nan Goldin ve Noboyoshi Araki; çağdaşlarına öncülük eden yaklaşımlarıyla yeni bir fotoğrafik anlatım alanı yaratan önemli fotoğrafçılar olarak kabul edilmektedirler.

\section{Nan Goldin}

"Fotoğrafçının röntgenci olduğuna dair popüler bir görüş vardır. Ben bunu yapmadım; bu benim partim" (Goldin, \& Coulthard, 1996). Nan Goldin'in, bu sözleri kendi ve yakın çevresinin yaşamını günlük tutarmışçasına yalın ve içerden anlatan fotoğraflarını ve kendi yaklaşımını özetler niteliktedir. 1953'te Washington'da doğan ve orta sınıf Yahudi bir ailenin iki kızından biri olarak Boston'da büyüyen Nan Goldin, fotoğraf çekmeye on beş yaşında Lincoln'deki Satya Community School'da başlar. Kendisini fotoğraf çekmeye yönelten neden, ablasının intihar etmesidir. "Ablamın öfkesini ve acılarını görüyordum ve o tek çıkış yolu olarak intiharı seçti. On bir yaşındaydım ve tarihin tekrar etmesinden korkuyordum. Fotoğraf çekmeye başlamıştım ve hiç kimsenin anısını kaybetmemek konusunda takıntılı hâle gelmiştim" (Goldin, \& Coulthard, 1996). Goldin'in devam ettiği okul, İngiltere'deki Summerhill School (1921 y1lında kurulan bu yatılı okul, çocukların okula değil, okulun çocuklara uygun olması felsefesini benimseyerek; tamamen demokratik yapıyı ve özgürlüğü savunur) örnek alınarak kurulmuş bir halk okuluydu. Sinıfların olmadığı ve özgür bir yapıya sahip olan bu okuldaki insanların birçoğu normal okullardan atılan öğrencilerdir. Ortalıkta çıplak dolaştıklarını, seviştiklerini ve bu yolla sosyal yetenekleri öğrendiklerini ve o andan itibaren fotoğraf çekmenin kendisinde bir 
saplantı hâline geldiğini söyleyen Goldin'in ilk konusu aradan geçen yıllara rağmen hâlâ en yakın arkadaşı ve kendisi gibi fotoğrafçı olan David Armstrong'dur. O yıllarda drag queen (kadın kılı̆̆ına giren erkek) olmaya başlayan David'le birlikte tüm drag queen topluluğuyla tanışan Goldin onlarla birlikte yaşamaya başlar ve arkadaşları onun yeni ailesi olur. Her gece birlikte gittikleri bar, mafya tarafindan işletilmesine rağmen Goldin'e sempatiyle yaklaşırlar ve onun her zaman barda fotoğraf çekmesine izin verirler. Böylece Goldin, barın fotoğrafçısı haline gelir ve yeni ailesiyle geçirdiği her anı fotoğraflar. Hiçbir zaman normal toplumun bir parçası olmak istemediklerini söyleyen Goldin ve ailesi, cinsel kimlik ayrımının olmadığı, birlikte özgür ve eşit koşullarda alternatif yaşam tarzı çizdikleri bir hayatı paylaşırlar. Boston'da School of the Museum of Fine Arts'ta eğitimine devam eden ve moda fotoğrafçısı olmak isteyen Goldin, çektiği drag queen fotoğraflarını Vouge Dergisi'nin kapağında hayal eder. 70'li yıllarda Goldin ve ailesi dönemin marjinal ruhuna uygun olarak gecelerini partilerde geçirirler ve diğer uyuşturucular gibi eroin de o zamanlar bağımlılık değil herkesin kullandığı bir parti uyuşturucusudur:

"Fotoğraflar bana bir gece öncesinde ne olduğunu hatırlatır. Fotoğraf çekmek, bana aynı anda hem kontrollü hem kontrol dişı olmamı söyler. Onlar benim hafizam olurlar" (Goldin, \& Coulthard, 1996).

Hiç kimsenin hatırasını kaybetmemek amacıyla kendisinin ve arkadaşlarının yaşamının her anını olduğu gibi kayıt altına alan Goldin bu fotoğraflardan oluşturduğu ilk dia gösterisini 1973'te Boston'da gerçekleştirir. 70'li y1lların sonuna doğru okuldan mezun olan Goldin ailesiyle birlikte New York'a taşınır. Burada, geç 70'ler ve 80'lerin başında, şehrin alt kültürüne ait eğlence mekânlarını, müzisyenleri, eşcinsellerin ve düzcinsellerin alternatif yaşamlarını ve uyuşturucu kültürünü fotoğraflayan Goldin, bu fotoğraflardan oluşturduğu seriyi 1982 y1lında, sonradan aynı adla en ünlü işine dönüşecek olan ve adını Bertolt Brecht'in Threepenny Opera (Üç Kuruşluk Opera) adlı eserindeki bir şarkıdan alan, The Ballad of Sexual Dependency adını verdiği dia gösterisi olarak sunar. Goldin bu gösteride fotoğraflarını sunduğu birçok arkadaşını 90'lı y1llarda yüksek dozda uyuşturucu ve AIDS yüzünden kaybeder. Goldin'in en yakın arkadaşlarından olan ve 'bizim süper yıldızımızdı' diye tanımladığı Cookie Mueller'ın yaşamı da Goldin'in fotoğraflarında belgelenir. Cookie, İtalya'ya gider ve orada sanatçı Vittorio Scarpati ile tanışır ve çift, birkaç yıl sonra Scarpati'nin New York'a gelmesiyle evlenir. İkisi de HIV pozitif olan Cookie ve Vittorio'nun kısa ve dramatik ilişkisinin anısı Goldin'in fotoğraflarında ölümsüzleşir. Vittorio'nun ölümünün ardından önce sesini kaybeden ve baston desteği olmadan yürüyemeyen Cookie, savaşmayı bırakır ve iki ay sonra o da hayatını kaybeder:

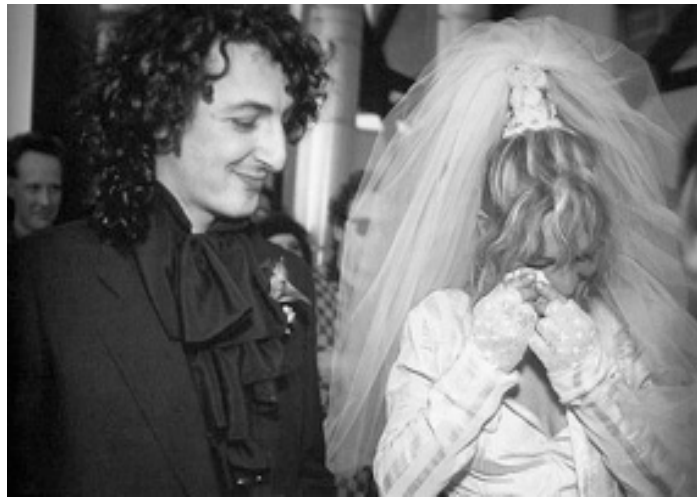

Fig 1. Nan Goldin, Cookie ve Vittorio'nun Düğünü, New York, 1986.

\begin{abstract}
"Eskiden, insanlarl yeterince fotoğraflarsam onlarl asla kaybetmeyeceğimi düşünürdüm. Aslında, fotoğraflartm bana, ne kadar çok kaybettiğimi düşündürüyor. Fotoğraflarım benim günlüğüm; insanları okuyabildiğim” (Goldin, \& Coulthard, 1996).
\end{abstract}

Goldin, fotoğrafları aracılığıyla ailesinin yaşamını içerden anlatırken, kendiyle ve yaşadıklariyla da hesaplaşmış; hatta çoğu kez kendini kurban etmekten çekinmemiştir. Goldin, sevgilisi Brian'la olan ilişkisinin gidişatına dair 
ipuçlarını, 'Nan and Brian in Bed (Nan ve Brian Yatakta)' ismini verdiği ve The Ballad of Sexual Dependency'nin en bilinen karelerinden biri olan bu fotoğraftan okur:

"Sevgilim Brian'la olan ilişkimi fotoğrafladim. Sevişirken seviştikten sonra. Tripod ve kablo denklanşörü kullaniyordum. Fotoğrafları görene dek, onların nasıl olabileceği hakkında bir fikrim yoktu. Ayarlamadım, düşünmedim, çizmedim, hiçbir şey yapmadım; sadece gerçekte ne olduğunu fotoğrafladım. Sonrasında fotoğraflara bakınca benim için çok anlamlı olduğunun farkına vardım. Seksten sonra aramızdaki mesafeyi gördüm, arkasını dönüp sigara içiyor ve ben hâlâ aramızdaki yakınlık adına ona baklyorum" (Klein, 1998).

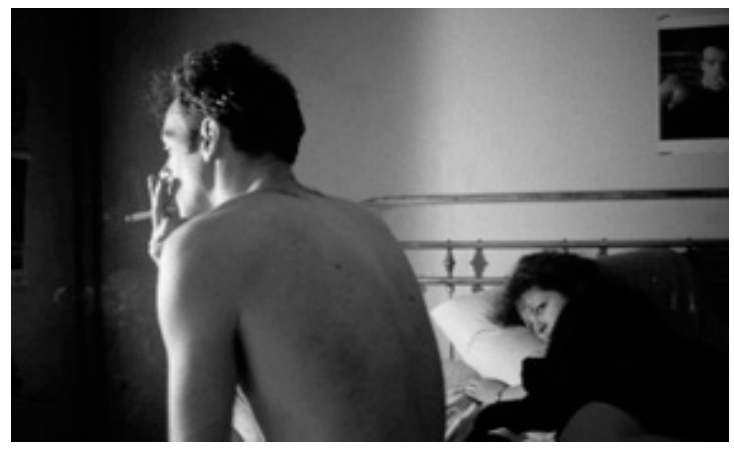

Fig 2. Nan Goldin, Nan ve Brian Yatakta, New York, 1983.

İlişkimizin bağımlılığı bizi neredeyse yok ediyordu dediği bu ilişki Goldin'in, sevgilisi tarafından ciddi bir şekilde dövülmesiyle son-

lanır. Hastanedeki tedavi sürecinden bir ay sonra yüzünü fotoğraflayan Goldin, bu fotoğrafi çektikten sonra bir daha sevgilisine geri dönmez. Çoğunlukla eroin ve kokain kullanan Goldin ve birçok arkadaşı, 80'lerin ortalarında, uyuşturucu kullanmak ve bağımlı olmak arasındaki çizgiyi aşarlar ve Brian'la olan ilişkisinin ardından duygusal olarak iyileşemeyen Goldin'in kokain kullanımı bağımlığa dönüşür: "Bazı arkadaşlarım uyuşturucuyu bırakmıştı; ama ben her geçen gün devam ettim. Parti bitmişti; ama ben duramamıştım” (Goldin, \& Coulthard, 1996). Yaşadığı bunalım nedeniyle odasına kapanan ve aylarca gün 1şı̆̆ından uzak yaşayan Goldin, 1988 'de Boston dışında bir uyuşturucu rehabilitasyon kliniğine yatar. Bir süre fotoğraf makinesinden uzaklaşır; ancak daha sonra tedavinin ortalarında yeniden kendini fotoğraflamaya başlar. Uzun bir aradan sonra, kamerasıyla olan ilişkisine kaldığı yerden devam eden Goldin, narkotik sarhoşluğun etkisi altında olmadan, ayık bir hâldeyken aynalardaki görüntüsünün peşine düşer. Uzun bir zaman dilimine yayılan madde bağımlılığının bedeni üzerinde yarattığı etkilerin ardından, arınmaya başladığı sürecin getirdiği iyileşmeyi, uyuşturucular olmadan kendi yüzünün nasıl göründüğünü, cildinin nasıl bir değişim geçirdiğini gözlemleyerek bunu fotoğraflarına yansitır.

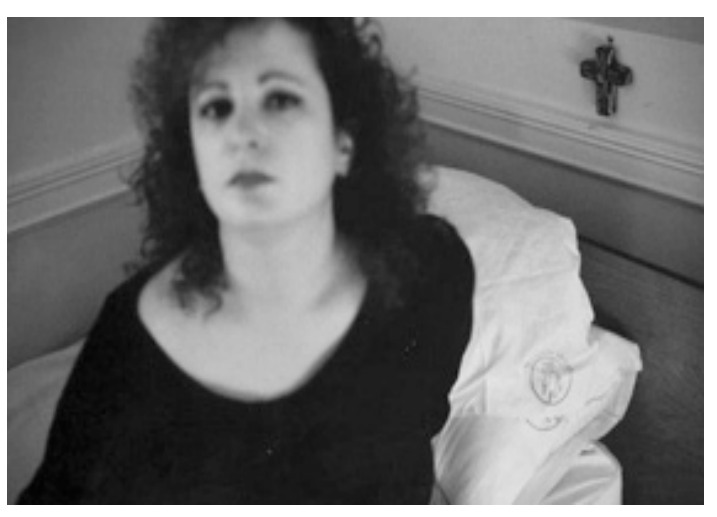

Fig 3. Nan Goldin, Milagro'yla Otoportre, The Lodge, Belmont, MA, 1988.
Şans getirdiğine inandığ 1 objeleri toplayan Goldin'in klinikteki odasında çektiği bu otoportrede duvarda asılı olan haç, sanatçının bu zor dönemde kendisine yardımcı olması için yanında getirdiği objelerden biridir. Kliniğin ambleminin yastık kılıfinda görünmesi, bu fotoğrafı çektiği anda bulunduğu mekânın bir ispatı; başka bir deyişle Goldin'in kendi yaşamının her anını saklamadan, olduğu gibi yansıtmasının bir göstergesidir. Birçok korkunun olduğu, hiçbir şeyin tanıdık gelmediği ve bir tür kimlik krizi yaşadığ 1 bu süreçte, gündüz saatlerinde dışarı çıkmayan Goldin'in yaşadığı tüm üzüntü odasına dolan 1şığın içindedir. On beş yıl boyunca 
'karanlıkta' yaşayan Goldin'in iyileşme sürecinin parçalarından biri gün 1şı̆̆ını keşfetmesidir: "O zaman ışığın renkli filmi böyle etkilediğini bilmiyordum. Böylece tüm işlerim ışıkla ilgili hale geldi. Hem metaforik hem gerçek anlamda; karanlıktan aydınlığa çıkmak”" (Klein, 1998).

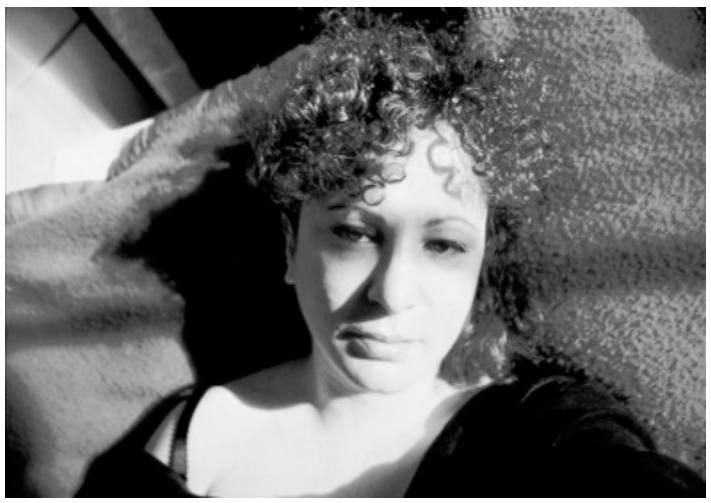

Fig. 4. Nan Goldin, İçe Dönük Gözlerle Otoportre, Boston, 1989.

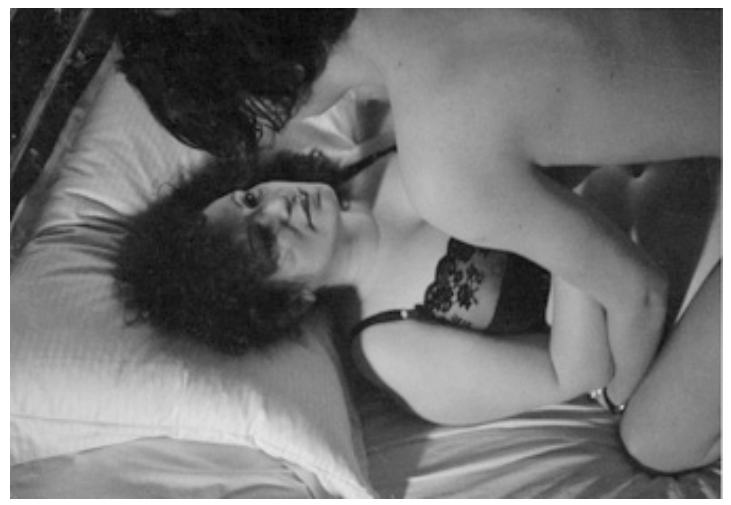

Fig. 5. Nan Goldin, Siobhan'la yatakta otoportre, NYC, 1990.

Rehabilitasyon sürecinden bir buçuk y1l sonra New York'a dönebilecek kadar güçlü hisseden Goldin, Siobhan adındaki genç bir kadın olan sevgilisiyle birlikte yaşamaya başlar. Sevgilisinin her gününü fotoğraflayan Goldin, sevişme anlarını da açık bir biçimde günlügüne dahil eder. Bu anlar onun için, uyuşturucunun etkisi altında olmadan, bir insanla ne kadar yakınlaşabileceğinin bir parçasıdır.

Yıllar boyu fotoğrafladığı insanların dışa dönük davranışlarıyla, onların ilişkileri, cinsellikleri ve toplumsal normların dışında yer alan cinsel kimlikleriyle ilgilenen Goldin; partiler, uyuşturucu, alt kültürler, eşcinsel ve trans kimliklerle çalışmanın her zaman yanlış anlaşıldığını ve tüm bunlara karşı ailesinin hâlâ marjinal olduğunu söylüyor:

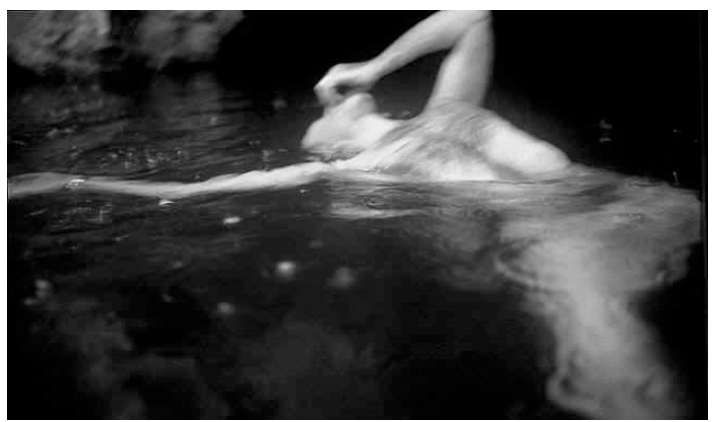

"Hiçbir zaman normal toplumun bir parçası olmak istemedik; bence işler öyle yürümüyor. Bunlar, daima insan olmanin koşullariyla, acıyla ve bedenin hayatta kalmastyla ve bunun ne kadar zor olduğuyla ilgili" (Klein, 1998).

Fig. 6. Nan Goldin, Guido yüzüyor, Levanzo, Sicilya, 1999.

Fotoğraf çekmeye başladığı andan itibaren kişisel yaklaşımıyla, klasik belgeselin dışında yer almak istediğini ve sadece kendisini ve ona yakın olan insanların hayatlarını fotoğraflamaya hakkı olduğunu düşünen Goldin için fotoğraf çekmek bir çeşit terapidir: "Fotoğraf, hayatımı kurtardı. Korkutucu bir dönemden geçtiğimde, travmatik olaylar yaşadı̆̆ıda fotoğraf çekerek ayakta kalmayı başardım” (Mazur, \& Krajewska, 2003). 


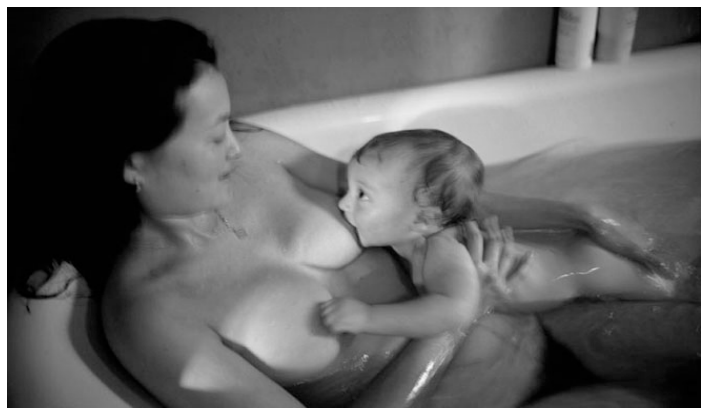

Fig. 7. Nan Goldin, Maria küvette Elio’yu emziriyor, Sag Harbor, 2001.

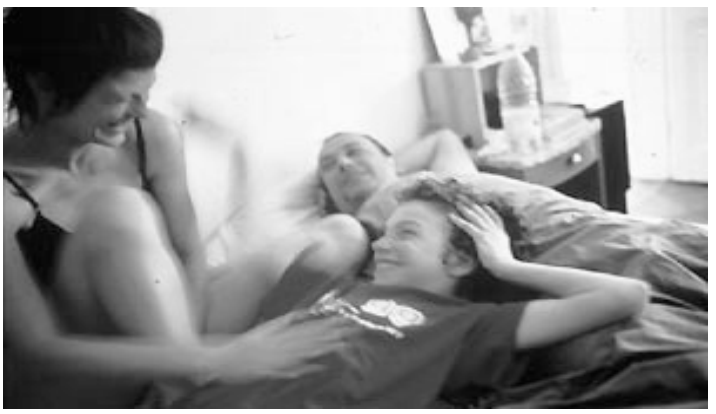

Fig 8. Nan Goldin, Valerie, Bruno ve Mel yatakta gülüyorlar, Paris, 2001.

Fotoğrafları, Goldin'in yaşadığı olayları, anılarını kayıt altına aldığı günlüğüdür; bunu fotoğraflarına verdiği isimlerden de okumak mümkündür. Goldin, kimlerle neler yaşadığını, hayatında yer alan insanları ve anılarını fotoğrafları aracılığıyla bize anlatmaktadır. Nan Goldin'in yaşamındaki dönüşümler, fotoğrafları üzerinden açıkça okunmaktadır. Goldin, hâlâ marjinal bir aileye mensuptur ancak rehabilitasyon sonrası yaşamındaki değişiklikler, 1995'ten sonra çektiği geniş bir yelpazeye yayılan fotoğraflar aracılığıyla anlaşılmaktadır. Rehabilitasyon sonrası ayık bir hayata başlayan Goldin için Siobhan'la yaşadığı ilişki de yeni bir duygusal deneyimdir, (bkz. Fig. 5) uyuşturucu etkisi altında olmadan; tamamen ayık durumdayken bir insanla yakınlaşmanın nasıl bir his olduğunu hem kendi deneyimler hem de bu anı, bu fotoğraf aracılığıyla bizimle paylaşır. Goldin, ailemizin yıldızıydı dediği Cookie Mueller ve İtalyan eşi Vittorio Scarpati'nin anılarını yaşatmak amacıyla arkadaşı Guido Costa ile Napoli'ye dönerek on yılda yaşamlarında neler değiştiğini eski ve yeni fotoğrafları biraraya getirerek bizlere anlatır. Önce Cookie ve Vittorio'nun ilişkilerinin mutlu günlerini, ardından onlar olmadan Goldin ve Costa'nın Napoli'yi nasıl gördüklerini görürüz (bkz. Fig. 6). Goldin ve Costa için, "Ten Years After" adını verdikleri bu kitap Cookie ve Vittorio'nun aşklarının anısına saygı duruşudur. Goldin ve arkadaşlarının toplumsal normların dışında seyreden yaşamlarının uzun yıllara yayılan fotoğrafları bir bütün olarak değerlendirildiğinde, ne kadar çok insanı kaybettiği ve ilk dönem fotoğraflarından okunan eğlencenin yerini acıya ve hüzne bıraktığı söylenebilir. Goldin'in son dönem çalışmalarını topladığı kitabı “The Devil's Playground"nda 90'lı yıllara ait fotoğrafları 'bir yüzyılın sonu' olarak sınıflanmakta ve 2000 yılından itibaren çektiği fotoğraflar çoğunlukla bebekleri, çocukları, ebeveynleri ve aile yaşamlarını anlatmaktadır (bkz. Fig. 7-8). Bu dönüşüm bir bakıma Goldin'in de yaşamında yeni bir yüzyıla girişi olarak kabul edilebilir.

\section{Nobuyoshi Araki}

"Fotoğraflartm benim günlügümdür. Her bir fotoğraf tek bir günü temsil eder ve her bir gün geçmişten geleceğe ışık tutar. Bu yüzden çektiğim her fotoğrafta, her bir günü göstermek zorundaymışım gibi hissediyorum. [...] Bu geçmişle gelecek arasında bir bağlantıdır. Şimdiki zamanı değerli kılan şey, geçmiş ve gelecek arasında bir yerde olmasıdır. Birini yakaladı̆̆ımda; ikisini birden yakaladı̆̆ımı hissedebiliyorum. Fotoğraf çektiğimde tüm anılarım silinir ve sonunda kamera hafizam haline gelir. Bana ne olduğunu, içimde ne gibi karlşıklıklar olduğunu insanlara anlatabilmem için sonunda kendimi fotoğraflarla ortaya koymam gerekiyor" (Klein, 2000).

1940'ta Tokyo'da doğan Nobuyoshi Araki, ilkokuldayken babasının verdiği makineyi yanına alarak gittiği bir okul gezisinde ilk fotoğrafını çeker. O andan itibaren fotoğraf çekmeye tutsak 
olan Araki, neredeyse tüm fotoğraflarını doğup büyüdüğü ve halen yaşadığı şehir olan Tokyo'da çeker. Onun fotoğrafladığı kent, 'shi Tokyo' (benim Tokyo'm) dediği ve kendi geçmişinin izlerini taşıyan, kalabalığın ve itiş kakışın ortasında yürürken kendi adımlarının sesini duyduğu, insan yoğunluğuna rağmen herkesin yalnız ve üzgün olduğunu görebildiği Tokyo'dur. Chiba Üniversitesi'nde fotoğraf ve sinema eğitimi alan Araki; yirmili yaşlarının başında İtalyan Yeni Gerçekçiliğinden esinlenerek Satchin'de yaşayan ve kendinden yansımalar gördüğü genç erkeklerin yaşamlarını fotoğraflar. Bu projesiyle ilk Taiyo ödülünü alır. İnsanların yüzlerinde her şeyi görebilirsiniz diyen Araki, bu çalışmasının ardından insanların ifadelerine odaklandığ sokak çekimleri yapmaya başlar. Araki'nin, Tokyo'ya yüklediği anlam geçmişinde saklıdır (Klein, 2000).

"Benim oyun bahçem mezarlıktı. Mahallemde bir mezarlık vardı ve çok özeldi. Yoshiwara genelev sokağının yanındaydl. Ailesi olmayan hayat kadınları öldüklerinde cesetleri oradaki toplu mezarın içine atılırdı. Mezar taşl ya da adları olmadan. Ben orada erotizmi, hayatı ve ölümü ögrendim. Ve şimdi nasıl hepsi bir araya gelip birbirine karışt. Bu kavramlar erken yaşta içime işledi ve sonsuza kadar bana bunları hatırlatacak. Bu benim Tokyo'mun; yaşam ve ölümün yan yana var olduğu bir şehir olan Tokyo'mun çekirdeği”' (Klose, 2004).

Araki için fotoğraf çekmek duygusal bir yolculuktur; "Onlardan birini okuduğumda bağırarak bir şeyler söylemeye çalışıyordu; o andan itibaren fotoğrafçıydım” (Klein, 2000) diyen Araki, evliliği de hayat boyu sürecek duygusal bir yolculuk olarak görür. 1971'de evlenir ve balay1 seyahatlerini fotoğraflar. Çiftin balayı, duygusal ve fotografik bir yolculuk olarak kendi deyimiyle manifestosuna hizmet eden ve Sentimental Journey (Duygusal Yolculuk) adını verdiği bir seri görüntüye dönüşür. Araki'ye göre duyguların iletişimi, konuşmaya gerek duymaksızın fotoğraf makinesi aracılığıyla kurulabilir; fotoğraf, anlık bir güçle yaşananların tüm özetini alabilir. Fotoğrafın neredeyse yanılsama olan bir gerçekliği vardır ve fotoğraf çekmek bunun farkına varmaktır. "Bu noktalar yaratmaya devam edersen hayatının yansıması olan çizgiler hâlini alırlar. Bu nedenle deklanşöre bastığım anda bu noktaların toplamını bilinçsizce düşünüyorum" (Klose, 2004). Bu yaklaşımla oluşturduğu balayı fotoğrafları, Araki'ye balayı yolculuğunun ötesinde, eşinin ölüme giden yolculuğuna dair bir izlenim verir. Yanagawa Nehri üzerindeki teknede eşi Yoko'yu uyurken fotoğraflar. Daha sonra bu fotoğrafa baktığında, ölümün ön duygusu olduğunu fark eder:

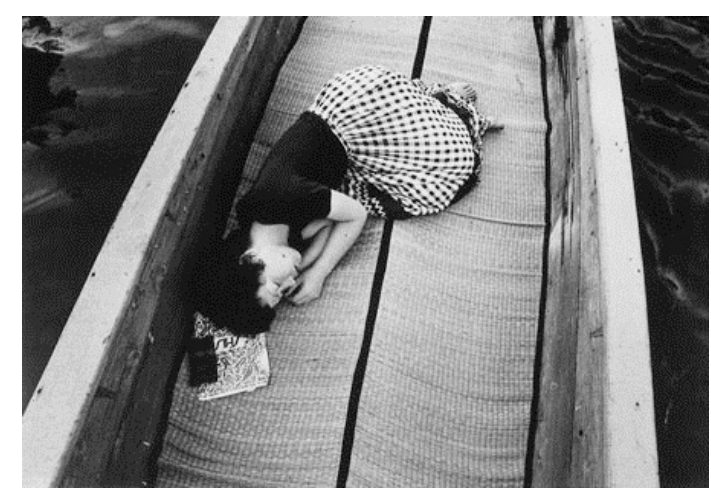

Fig. 9. Nobuyoshi Araki, Sentimental Journey, 1971.

\begin{abstract}
"O uyuyordu, gerçekte çok yorgundu ve o fotoğrafi düşünmeden çektim. Ama bakın cenin pozisyonunda uyuyor; çünkü tekrardan başa dönmek istiyordu. Yakından bakarsanız, onun ölüm nehrini geçtiğini düşünebilirsiniz. İşte o anda balayımızı ölüm yolculuğu olarak fotoğrafladiğımı anladım" (Klein, 2000).
\end{abstract}

Daha sonra eşi bir yaz günü Araki’ye, rahminde bir sorun olduğunu ve doktorların dediğine göre çok fazla zamanının kalmadığını söyler. Bu Araki'ye göre, eşinin yaşadığı son yaz mev- 
simi ve kışın başlangıcına olan yolculuğudur; çünkü kış ölümdür. Hastanede çekilen bu fotoğrafinda Araki eşiyle son kez el ele tutuşur. Eşi bilincini yitirmiş olmasına rağmen onun elini sımsıkı tutar ve bu anı kaydetmek için odada bulunan kardeşine fotoğraf makinesini verir ve bu açıdan fotoğraflarını çekmesini ister. Eşinin ölüm yolculuğunu ve onun ardından değişen yaşamının detaylarını ve kendi hislerini yansıttığı fotoğraflarını Winter Journey adını verdiği bir seriye dönüştürür. Yoko'nun ölümünden bir yıl sonra balkonundan sadece gökyüzünü fotoğraflar. Eşinin bulutların ardında bir yerlerde olduğunu ve bir şekilde onu görebileceğini düşünerek tüm zamanını gökyüzüne bakarak ve fotoğraf çekerek geçirir.

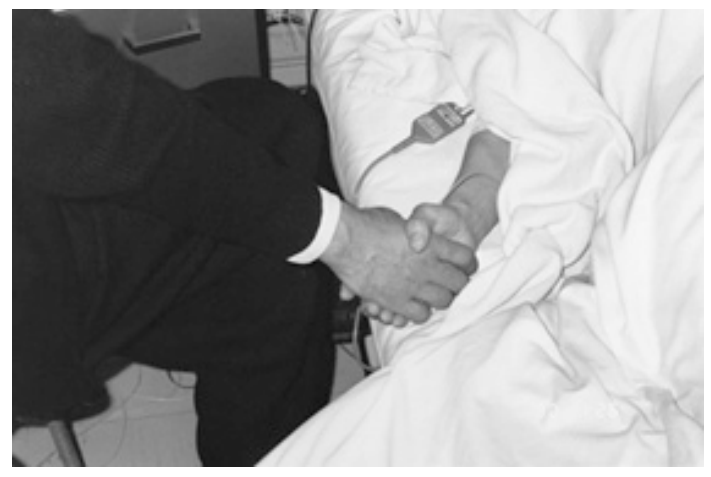

Fig. 10. Nobuyoshi Araki, Winter Journey (K1Ş Yolculuğu), 1989-1990

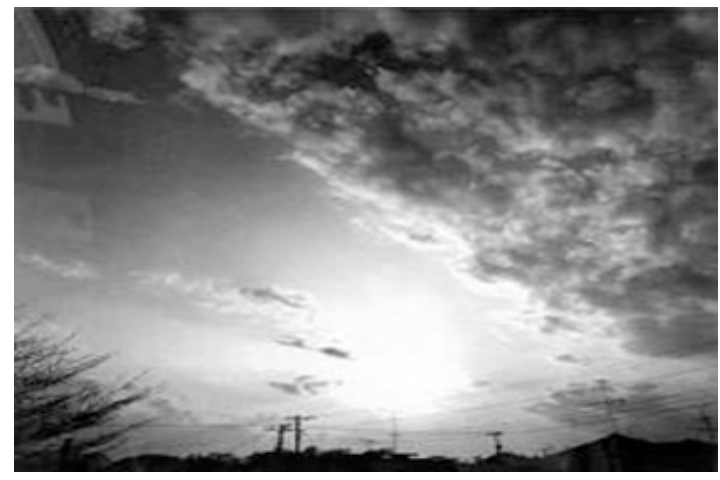

Fig. 11. Nobuyoshi Araki, İsimsiz

Araki'ye göre, ardında Yoko'yu aradığı bulut fotoğrafları alışıldık bulut fotoğraflarından farklıdır. "Herkes yaşamdaki hüznü hisseder. Bu yüzden, fotoğraf duygusal bir yolculuktur. Bir adam üzgün olduğunu asla göstermemelidir. Acı çekiyor olsa bile, bunu içinde tutmalıdır. Fotoğraf çekerek bu duyguları silmelisin. Böylece, o duygular gider" (Klose, 2004).

Eşinin ölümünün ardından Araki’nin fotoğrafları değişir. 70'li yıllarda çok tutucu olduğunu ve sonunda kendine karşı isyan ederek geçmişi yıktığını belirten Araki, kendi deyimiyle kirli tarafına dokunur ve böylece erotik dünyayı yeniden ziyaret eder. Ürettiği işlerin niteliklerine bağlı olarak Araki'nin fotoğrafları geniş bir çeşitlilik gösterir; ancak temelde hepsi aşk, cinsellik ve ölüm hakkındadır:

"Cinsel olarak ve bilinçsizce kendimi kadın için çizilmiş buldum. Kadın bedeninin değişken şeklinden ve kıvrımlarından; cildin ateşinden ve yapışkanlığından hoşlandım. Görsel sanatların kökeni vajinada yatar. Kadınların hayranlık uyandıran özellikleri erkeklerden daha fazladır; fiziksel ya da zihinsel olarak kadınlar daha üstündür. Her zaman annenin etkisi vardır; çünkü hepimiz kadınlardan geliyoruz. Örneğin, çocukluğumu çok iyi hatırlayamasam da bir gün annemi çok yüksek sesle ağlarken gördüm. Bu benim en şok edici anımdır. Gözyaşlarını asla göstermezdi. Bu anı daima zihnimin arkasinda durur; bu yüzden onu gizlemeye, üstünü örtmeye çalıştım. Onun ölümünü fotoğrafladım. Bu nedenle anneme duyduğum hisler bu kadar güçlü. Sadece alışıldık anne-oğul etkilenmesi değil; bundan çok daha fazla kişisel” (Klose, 2004).

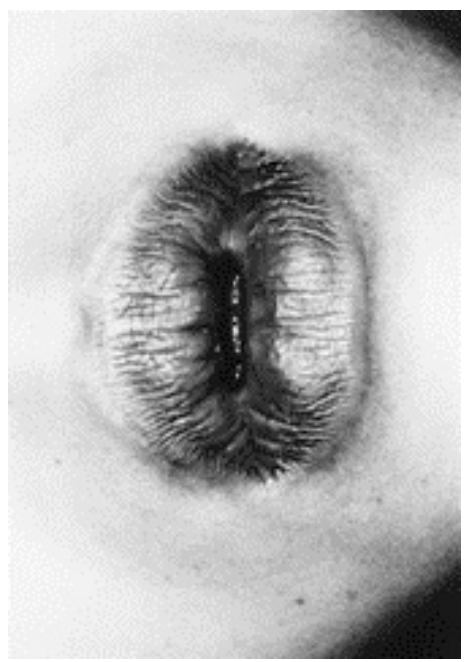

Fig. 12. Nobuyoshi Araki, İsimsiz, 1993. 
Araki'nin erotik fotoğrafları geniş bir çeşitlilik gösterir ve yayınlandıkları/sergilendikleri alanlar dikkate alındığında pornografik içerikli dergilerden Japonya'nın saygın galerilerine uzanan bir yelpazeye yayılır. Araki için fotoğraf, en basit haliyle sadece fotoğraftır; sanatın ne olduğuyla ilgilenmeden yalnızca etkileşim içinde bulunduğu nesneleri, onları gördüğü şekliyle fotoğraflar. Önceleri Araki'nin erotik fotoğrafları, edepsiz ve pornografik olarak değerlendirilirken 90'larda popülerliğinin yönü değişmeye başlar. Büyük müzelerde açtığı kişisel sergiler onun daha fazla tanınmasını ve insanlar tarafından edepsiz bir fotoğrafçıdan daha fazlası olduğunun anlaşılmasını sağlar. Bu sayede itibarı sağlamlaşır. Öte yandan Araki'nin fotoğrafları Japonya'da çıplaklığa karşı olan yaygın görüşün değişmesinde etkili olur. Ondan önce çıplak bir kadının fotoğrafı, ya sanat eseri ya da pornografik bir unsur olarak iki şekilde sınıflanırken Araki, yaklaşımıyla bu görüşe karşı çıkmış ve birbirinden kesin olarak ayrılan bu iki unsuru bir araya getirmiştir. Araki'ye göre bir kadının çıplak olması, soyunmuş olması anlamına gelmez, hatta üzerinde kıyafetleri varken kadınların çıplak fotoğraflarını çektiğini söyler. Onun için çıplaklık kadınların göğüslerinin, kasık tüylerinin ya da cinsel organının görünmesi değildir, çıplaklık kadınların yüzlerinde görünmelidir.

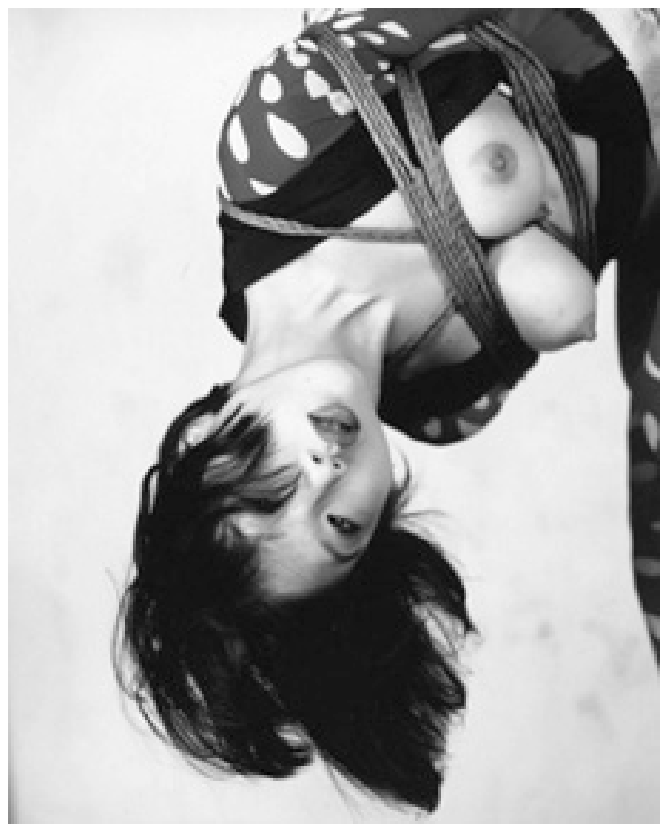

Fig. 13. Nobuyoshi Araki, Yamorinski and Bondage Woman, 2007.

Araki, en bilinen serilerinden olan Bondage (Köle) fotoğraflarında modelleri iplerle bağlayarak ve kimi zaman yüksek bir yere asarak fotoğraflar. Sadomazoşizm izlenimi veren bu fotoğraflar, sergilendikleri ülkelerde feminist gruplarca protesto edilmiş; bazı eleştirmenler tarafindan cinsiyet ayrımcıllı̆ı yaptı̆̆ ve kadınları küçük düşürücü bulduğu gerekçesiyle bu fotoğraflara şiddetle saldırılmışıır. Ancak tüm bu tepkilere rağmen Japonya'da birçok kadın Araki'ye modellik yapmaktan zevk duymaktadır.

Genel olarak yaşamın canlılığını çağrıştıran çiçek fotoğraflarının anlamı Araki’ye göre erotizm ve ölümü sembolize eder. Başlangıçta her türlü çiçeğin fotoğrafını çeken Araki, sonraları çiçeğin kalbine yakınlaşır. Araki'nin, ölümden ilham alarak fotoğrafladığı ve stilize detaylara odaklandığı çiçek fotoğrafları, cinsel organlara dair metaforlardır. Araki'nin fotoğraflarının konuları çeşitlilik gösterse de ana teması aşk, erotizm ve ölüm üçgeni üzerine kuruludur. Ona göre fotoğrafın anlamı da bu temada saklıdır ve onu, asla terk etmek istemediği, yaşam ve ölümün karışımını hissettiği Tokyo' da bulur. Yaşam ve ölümün anlamını siyah-beyaz ve renkli filmlerle yansitır. "Siyah-beyazın dünyasına girerim ve ölümü tecrübe ederim; sonra renklerin dünyasına girerim ve yaşamı tecrübe ederim. Yaptığım bu ikisinin arasinda gidip gelmek" (Klose, 2004).

\section{Sonuç}

İnsan, doğası gereği sosyal çevrenin bir parçasıdır ve bu durumun gerektirdiği birçok kimliği de bünyesinde barındırır. Bu kimlikler aynı zamanda birer aidiyet göstergesidir; ancak kişiyi bir diğerinden farklı kılan kendi öz kimliğidir. Bireyin, kendini bilme uğraşının ardında yatan ve anlamlandırma çabasında olduğu kimliği de budur. Kendi ‘öz'ünü bilme ve anlamlandırma çabası içinde olan sanatçı kimliğini, bir ifade aracı olarak gördüğü sanat yoluyla oluşturmaktadır. 
Sanatçının kimliğinin oluşumunda onu çevreleyen ve etkileyen dış dünyanın, yaşadıklarının ve kendi iç dünyasının yansımaları büyük önem taşımaktadır. Tüm bu etkenler biraraya geldiğinde sanatçının yaratım sürecine büyük etkisi olan geçmiş yaşantıları ve bunların duygusal ağırlıkları sanatsal üretimin ana temaları hâline gelmektedir. Bu çalışmada ele aldığımız Nan Goldin ve Nobuyoshi Araki'nin, yaşam öykülerini kaynak alan fotoğrafları sanatçının geçmişinin onun öz kimliğini oluşturduğuna dair somut örneklerdir.

Nan Goldin'in fotoğraflarının bu kadar

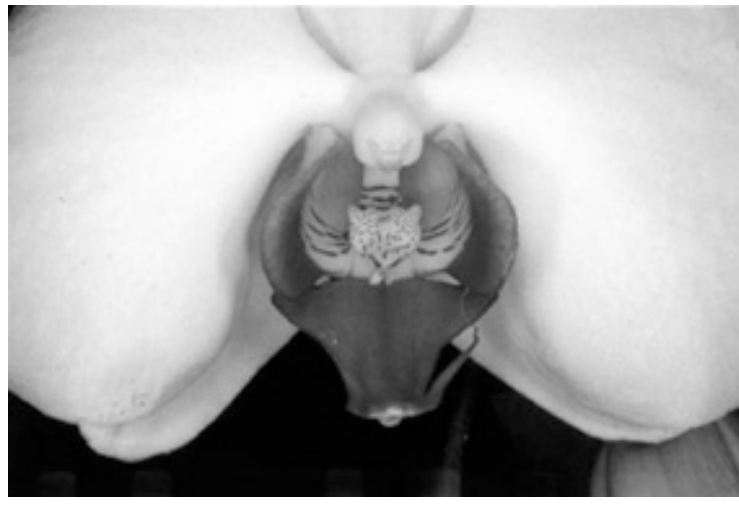

Fig. 14. Nobuyoshi Araki, Hana Jinsei serisinden, 2002.

yalın ve içerden anlatıma sahip olması, hatta izleyicide sanki aile albümüne bakıyormuş gibi bir izlenim yaratması, onun teknik/estetik kaygılardan bağımsız olarak sadece yaşadığı anın kayıt altına alınması güdüsüyle hareket etmesinden kaynaklanmaktadır. $\mathrm{Bu}$ yaklaşım, ablasının intiharının, Goldin'in iç dünyasında yarattı̆ğ duygusal sarsıntının bir sonucu olarak görülebilir. Ablasının kaybından sonra, herkesin hatırasını saklamak konusunda takıntılı hale geldiğini, bu yüzden kendisinin ve tanıdığı herkesin her anını fotoğrafladığını belirtmektedir. Öte yandan yaşam deneyimlerinin sanatsal üretim sürecinin odak noktası hâline gelmesiyle oluşturulan yapıtlar, yaratıcıları tarafindan bir çeşit kendi kendine terapi yolu olarak düşünülmektedir. Goldin'in çalışmaları da onun kişisel hesaplaşmasının bir parçası olarak değerlendirilebilir ve bu sözleri de bu görüşü destekler niteliktedir: "Fotoğraf, hayatımı kurtardl. Korkutucu bir dönemden geçtiğimde, travmatik olaylar yaşadiğımda fotoğraf çekerek ayakta kalmayı başardım" (Mazur, \& Krajewska, 2003). Goldin'in 73 yılında düzenlediği ilk dia gösterisinden son dönem fotoğraflarına tarihsel sırayla bakıldığında, David başta olmak üzere trans ve eşcinsel arkadaşlarıyla mafya tarafından işletilen barda geçirdikleri geceler, Cookie ve Vittorio'nun ölümle sonuçlanan kısa ve dramatik aşkları, Goldin'in sevgilisi Brian'la olan sorunlu ve şiddet dolu ilişkisinin ardından gelen uyuşturucudan kurtulma süreci, yeni bir duygusal deneyim olarak nitelediği Siobhan'la ilişkisi, Avrupa yolculukları, ebeveynler ve çocukları, gizemli manzaralar bize Nan Goldin'in yaşamını açıkça göstermektedir. Goldin gibi Araki'nin fotoğrafları da kaynağını benzer yaşamsal deneyimlerden almaktadır ve Araki'ye göre fotoğraf çekmek yaşamsal acılardan arınmanın bir yoludur, "Herkes yaşamdaki hüznü hisseder. Bu yüzden, fotoğraf duygusal bir yolculuktur. Bir adam üzgün olduğunu asla göstermemelidir. Acı çekiyor olsa bile, bunu içinde tutmalıdır. Fotoğraf çekerek bu duyguları silmelisin. Böylece, o duygular gider" (Klose, 2004). Yoko'yla çıktıkları balayı yolculuğuyla başlayan ve eşinin ölümüne dek uzanan süreci ve bu kaybın ardından eşinden miras kalan kedisinin rehberliğinde kendini yeniden var etmesini Sentimental Journey (Duygusal Yolculuk) adını verdiği fotoğraf serisinden okuyabilmekteyiz. Bu sürecin ardından kirli tarafına dokunarak erotik fotoğraflar çekmeye başladığını söyleyen Araki'nin çalışmaları; yaşam ve ölümün bir arada var olduğunu söylediği Tokyo'ya olan bağlılığı ve kendi geçmişine dair çözümlemelerini de içeren aşk, erotizm ve ölüm üçgeninde devam etmektedir.

Kimlik bir oluşum sürecidir ve sanatçı kimliği de bu sürecin parçasıdır. Bu bağlamda Nan Goldin'i ve Nobuyoshi Araki'yi, oldukları kişiler hâline getiren yaşadıkları kişisel deneyimler ve bunları sanatsal üretimlerine konu edinerek bir çeşit içsel hesaplaşma ya da uzlaşmaya dönüştürmeleridir. Başka bir deyişle, onların sanatsal kimliklerini oluşturan duygusal geçmişleridir. 


\section{KAYNAKÇA}

Aşkın, M. (2007). "Kimlik ve Giydirilmiş Kimlikler”. Atatürk Üniversitesi Sosyal Bilimler Enstitüsü Dergisi, 10, 213-220.

Cebeci, O. (2008). Psikanalitik Edebiyat Kuramı. İstanbul: İthaki Yayınları.

Ezici, A. K. (2005). "Sanatçının Kişiliği ve Yaratma Psikolojisi”. Anadolu Psikiyatri Dergisi, 6, 122-127.

Güney, M. (1999). "Sanat, Benlik Nesnesi ve İlham”. Klinik Psikiyatri Dergisi, 1, 42-45.

Goldin, N., \& Costa, G. (1998). Ten Years After. Italy: Scalo Puplishers.

Goldin, N. (2008). The Devil's Playground. London: Phaidon Press Limited.

May, R. (2008). Yaratma Cesareti. Çev. Alper Oysal. İstanbul: Metis Yayınları.

Kılıçbay, M. A. (2003). "Kimlikler Okyanusu”. Doğu Batı Dergisi, 23, 155-159

Takış, T. (2003). "Kimliklerle Buluşma". Doğu Batı Dergisi, 23, Önsözden alıntı.

Takış, T. (2009). "Kişinin Kendisiyle Savaşı". Doğu Batı Dergisi, 48, 7-8.

Uysal, A. (2006). "Sanatçının Kimlik Arayışı". Dokuz Eylül Üniversitesi Buca Eğitim Fakültesi Dergisi, 19, 116-119.

\section{İnternet Erişimleri}

Mazur, A., \& Krajewska, P. S., (2003). Interview with Nan Goldin. Kaynak: http://fototapeta.art.pl/2003/ ngie.php

\section{Film}

Goldin, N. (Director), \& Coulthard, E., (Director). (1996).I'll Be Your Mirror [Documentary Film]. Blast! Films, Illuminations Television Für BBC Worldwide.

Klose, T. (Director). (2004). Arakimentari. [Documentary Film]. USA.

Klein, W., (1998).Contacts, Nan Goldin. [Documentary Film]. France.

Klein, W., (2000).Contacts, Nobuyoshi Araki. [Documentary Film]. France. 